Supplement of Clim. Past, 14, 637-651, 2018

https://doi.org/10.5194/cp-14-637-2018-supplement

(C) Author(s) 2018. This work is distributed under

the Creative Commons Attribution 4.0 License.

(c) (1)

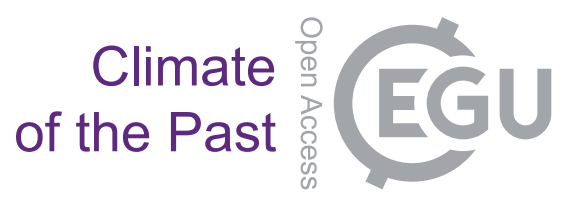

Supplement of

\title{
Aromatic acids in an Arctic ice core from Svalbard: a proxy record of biomass burning
}

M. M. Grieman et al.

Correspondence to: Mackenzie M. Grieman (mgrieman@uci.edu)

The copyright of individual parts of the supplement might differ from the CC BY 4.0 License. 


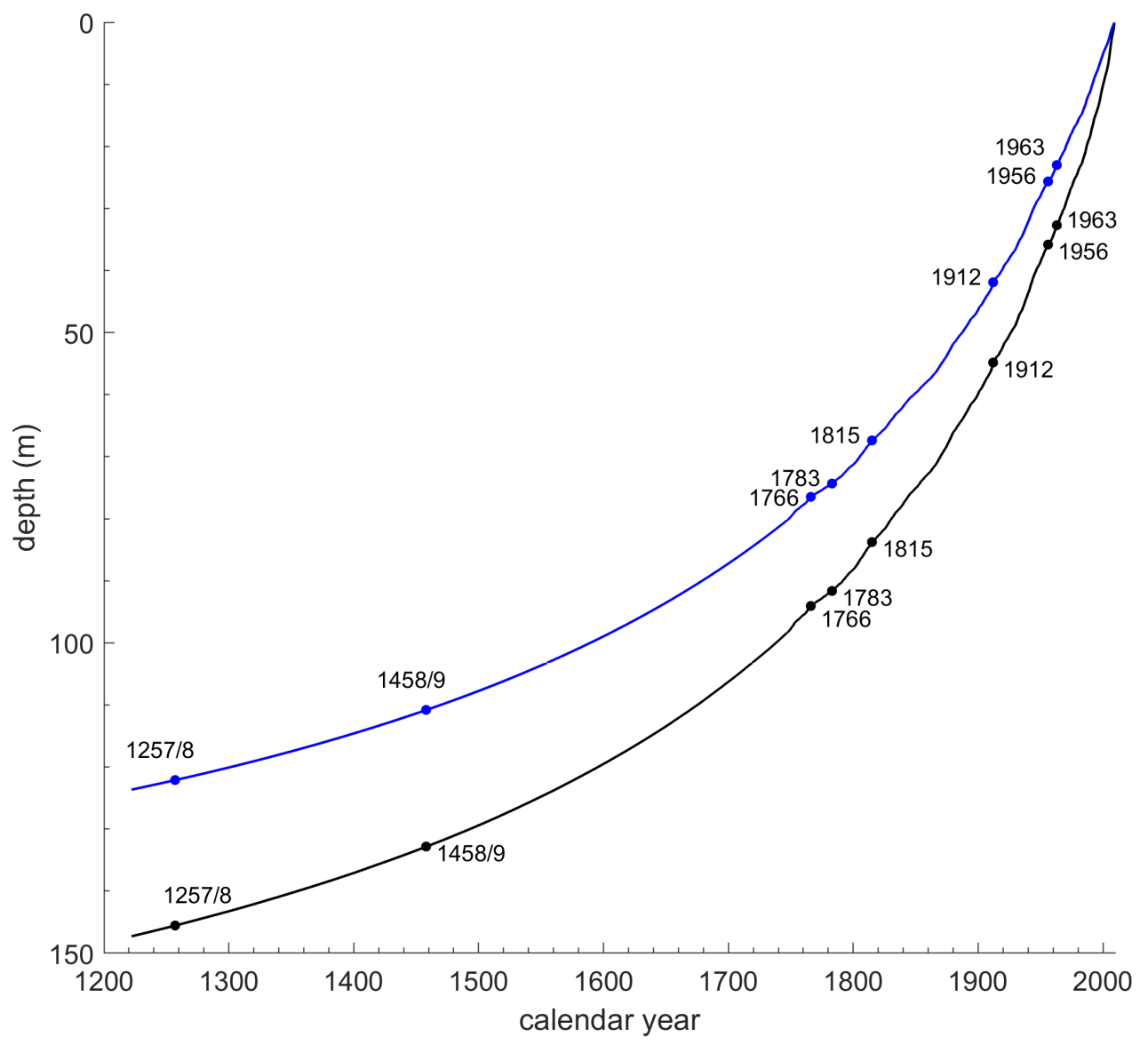

Figure S1. Lomonosovfonna ice core depth-age scale (adapted from Wendl et al., 2015). The black curve is the depth in meters. The blue curve is the depth in meters water equivalent. The points indicate tie points. These tie points are all volcanic eruptions, except for a tritium peak in 1963. 

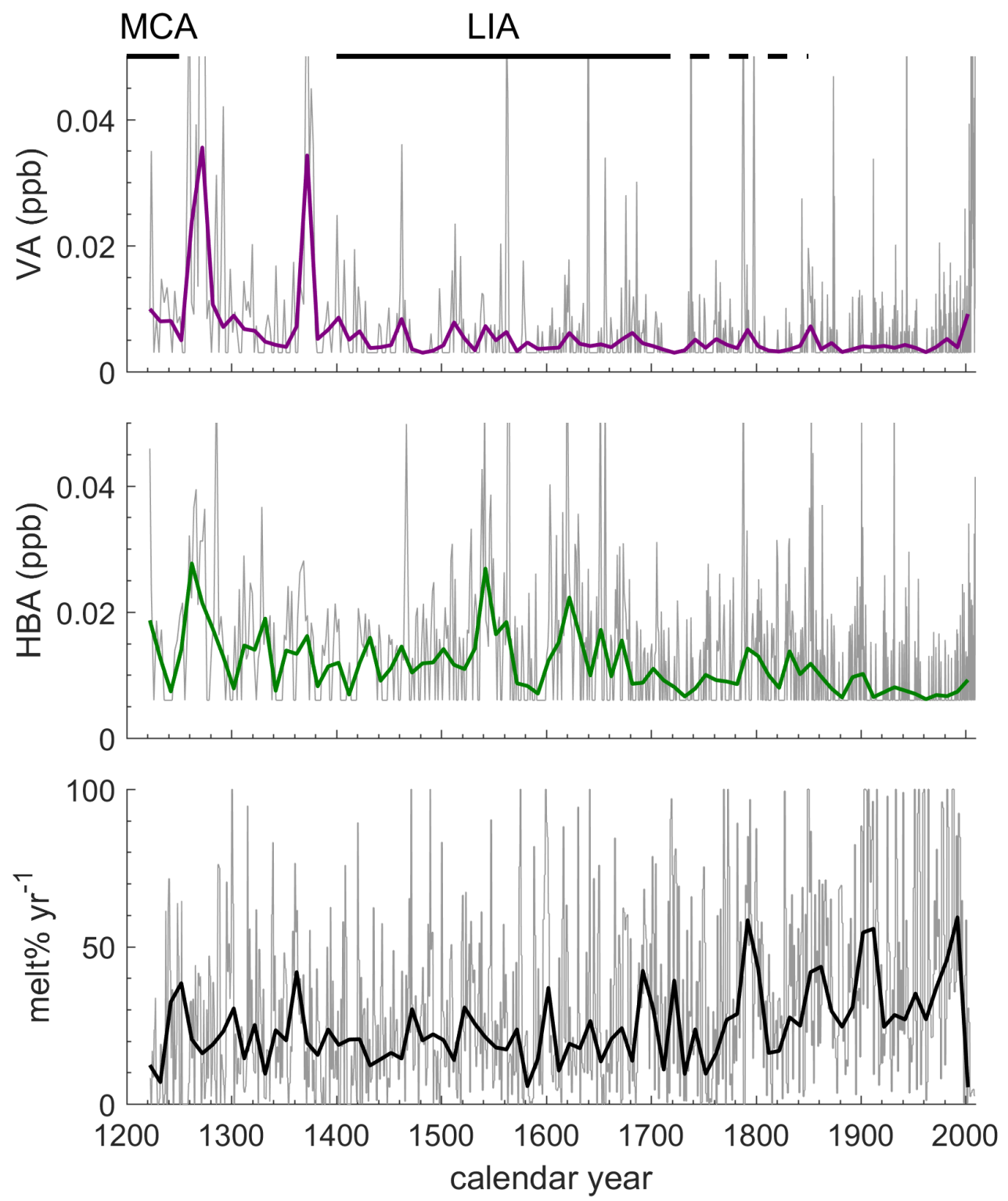

Figure S2. Lomonosovfonna melt layers (Wendl et al., 2015). From top: 1) Lomonosovfonna VA (167 $\rightarrow$ 152), 2) Lomonosovfonna p-HBA, 3) annual average melt percentage. Gray lines are individual data points. Black lines are 10-year bin averages. The black horizontal lines are the Medieval Climate Anomaly (MCA) and the Little Ice Age (LIA) (Mann et al., 2009). The dashed horizontal line is the extended LIA in the Svalbard region (Divine et al., 2011). 


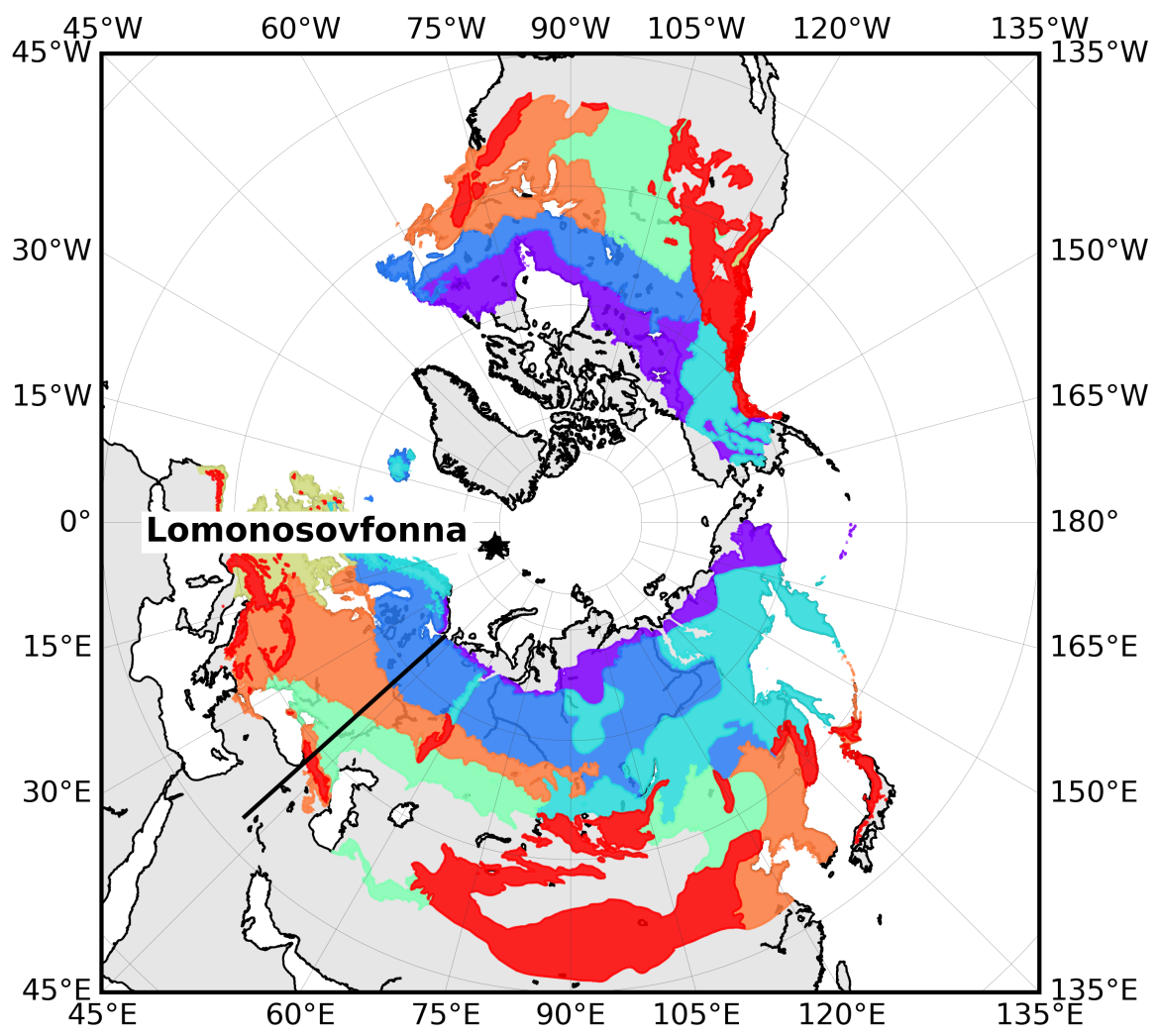

Figure S3. Ecofloristic zones as they are defined by the Food and Agriculture Organization. 


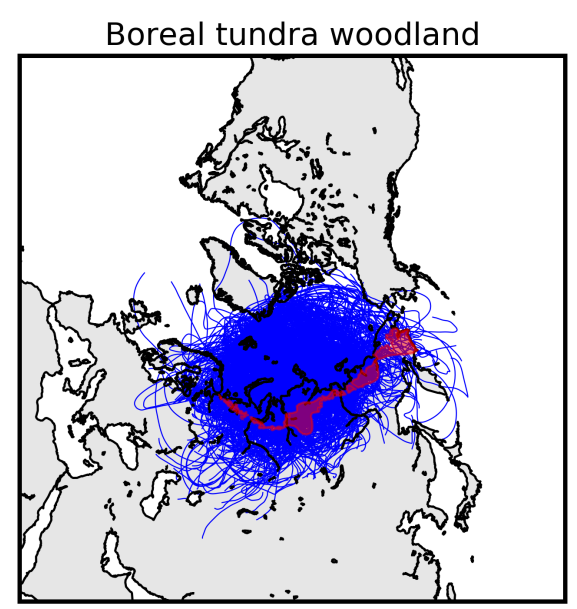

Boreal mountain system

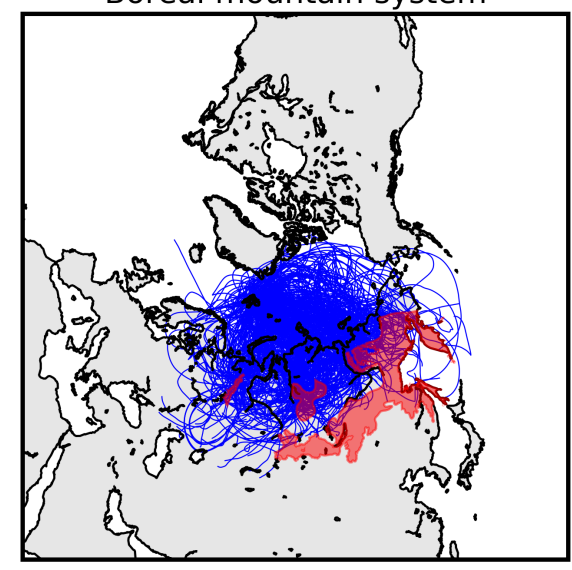

Temperate continental forest

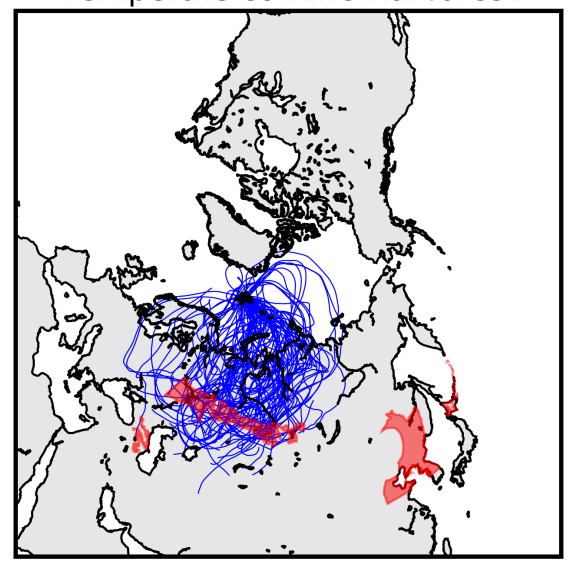

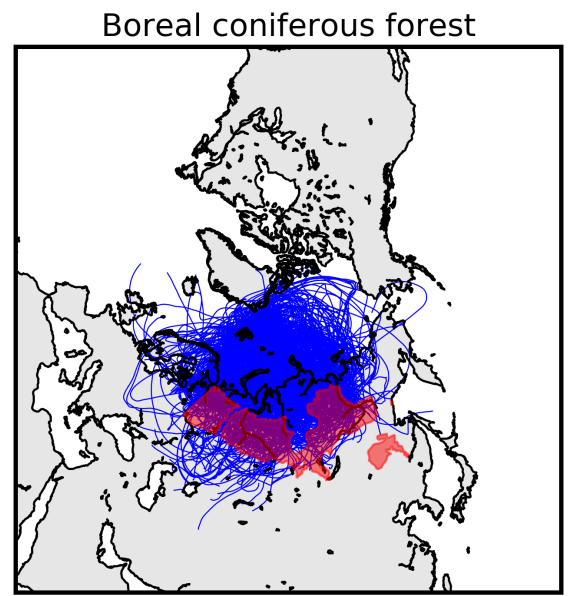

Temperate steppe

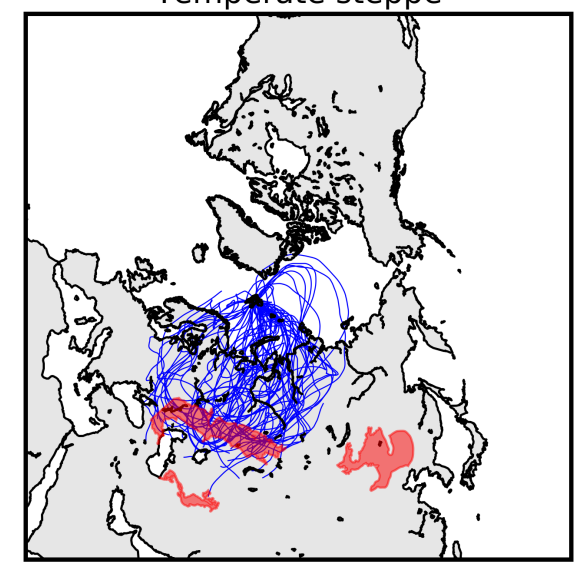

Temperate mountain system

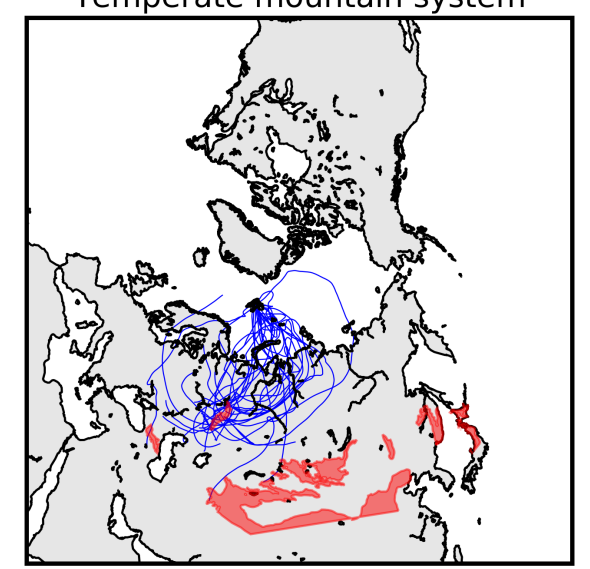

Figure S4. Back trajectories reaching Siberian ecoflorisitic zones. Blue lines are back trajectories reaching the specified ecoflorisitic zones from March-November 2006-2015. Red areas are the ecofloristic zones. 


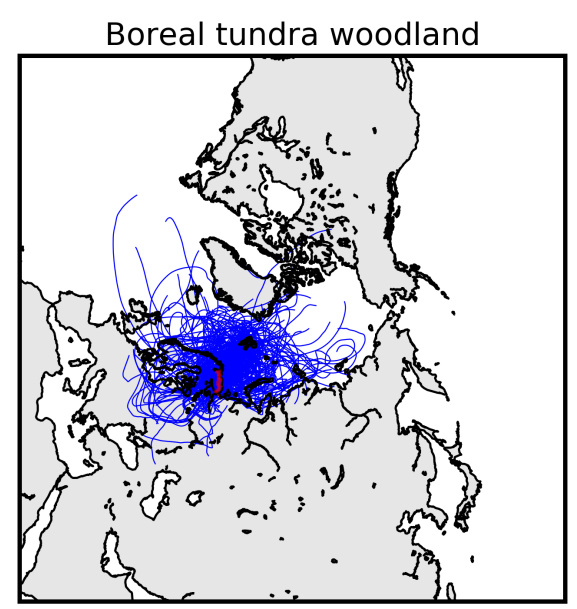

Boreal mountain system

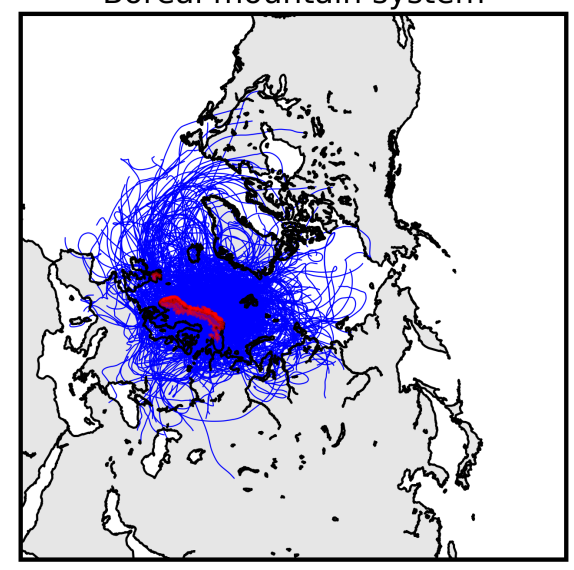

Temperate continental forest

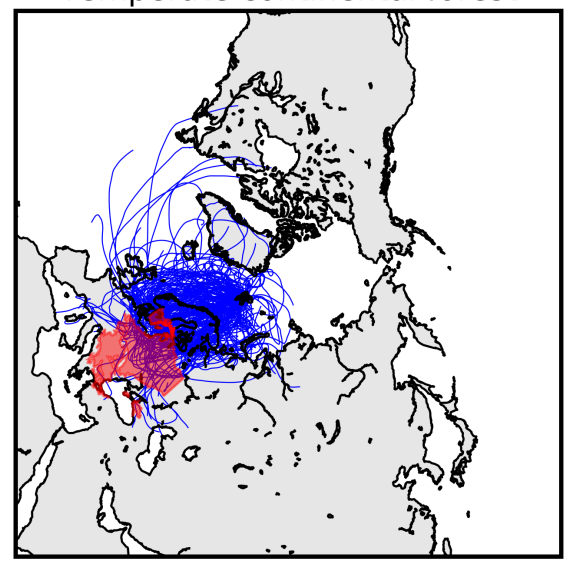

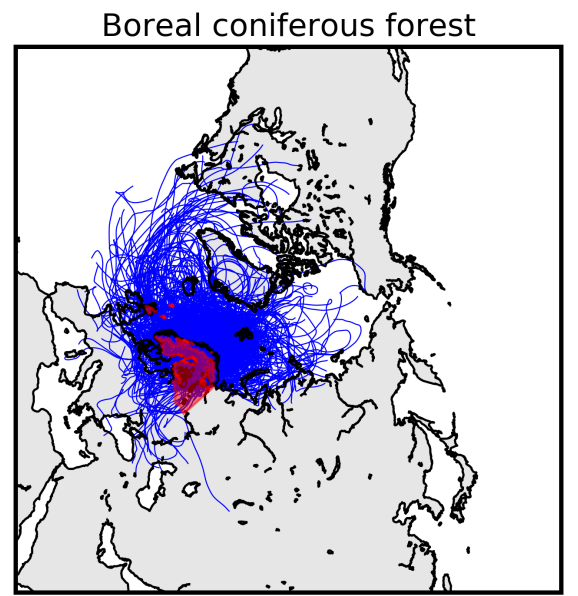

Temperate steppe

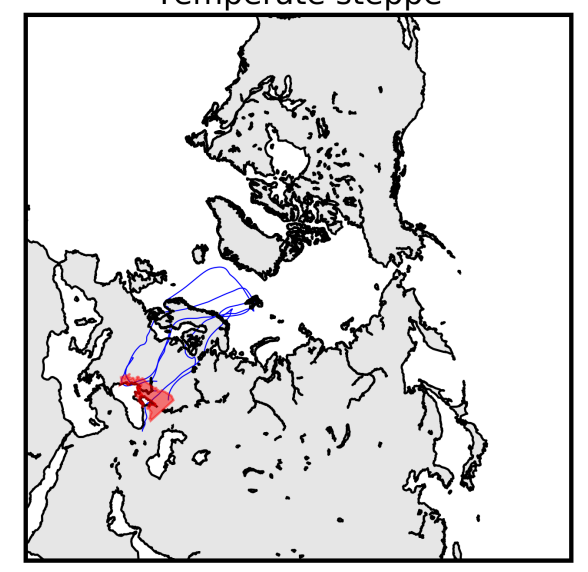

Temperate mountain system

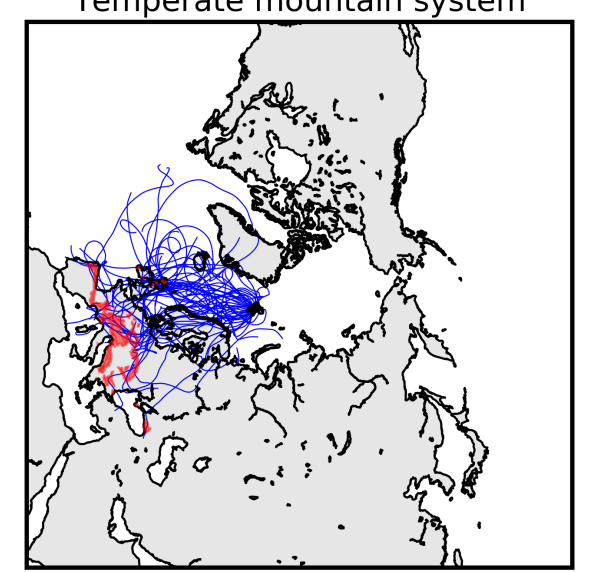

Figure S5. Back trajectories reaching ecoflorisitic zones in Europe. Blue lines are back trajectories reaching the specified ecoflorisitic zones from March-November 2006-2015. Red areas are the ecofloristic zones. 


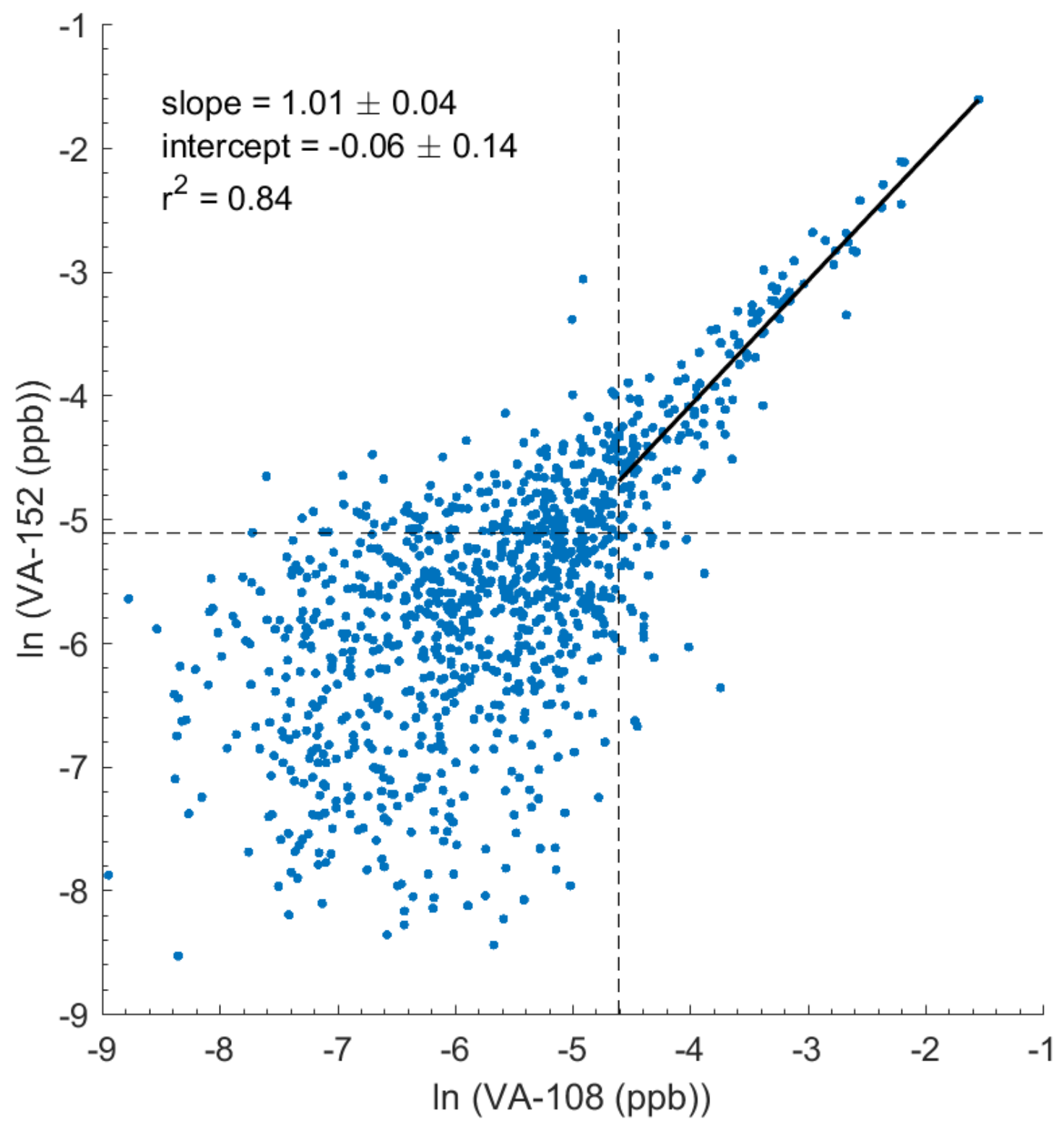

Figure S6. Relationship between two VA mass transitions $(\mathrm{m} / \mathrm{z} 167 \rightarrow 108$ and $167 \rightarrow 152)$. Black line is the linear fit of the log-transformed data above their respective limits of detection. The dashed lines are the log-transformed limits of detection for each transition. The standard errors of the slope and intercept are displayed. 

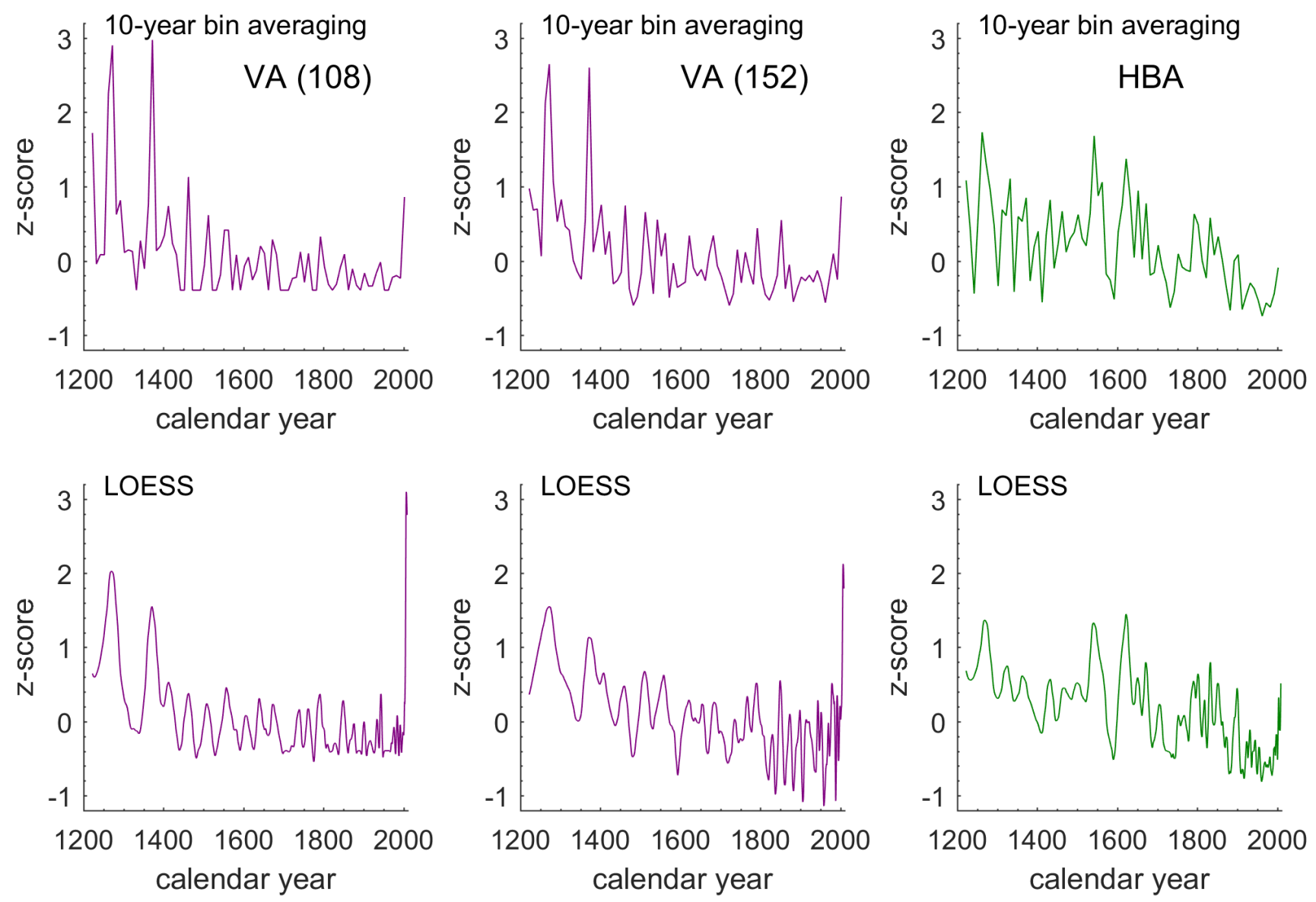

Figure S7. Lomonosovfonna VA (left: $\mathrm{m} / \mathrm{z} 167 \rightarrow 108$, middle: $\mathrm{m} / \mathrm{z} 167 \rightarrow 152$ ) and p-HBA (right) using 10-year bin averaging (top) and LOESS smoothing ( span $=0.04)$ (bottom) of the log transforms. Data were normalized using the mini-max transformation and the $\mathrm{z}$-score. 


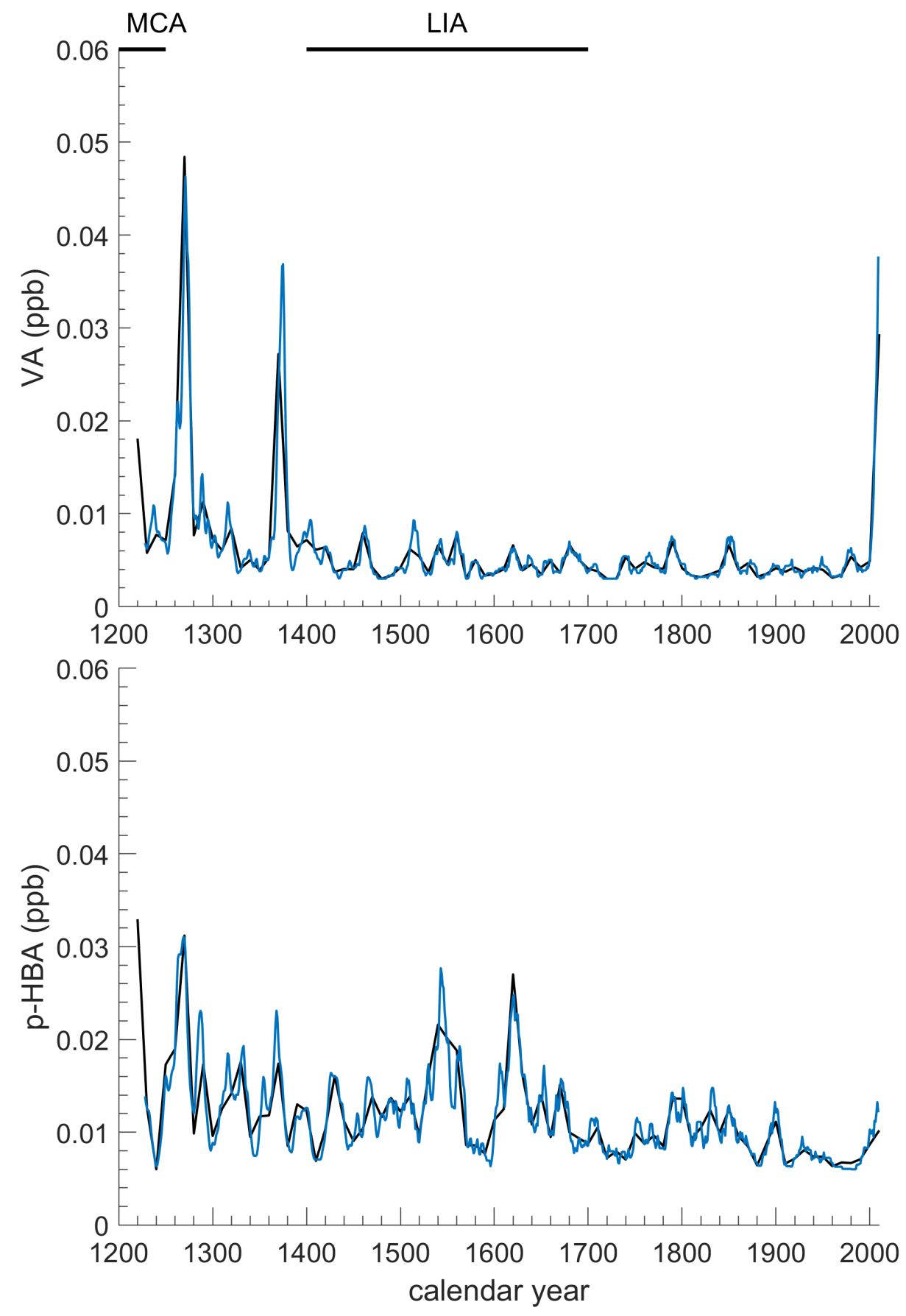

Figure S8. Lomonosovfonna VA (top) and p-HBA (bottom) using 10-year bin averaging of the log transforms (black) and 10-year moving averages of annually-interpolated log transforms of the data (blue). 

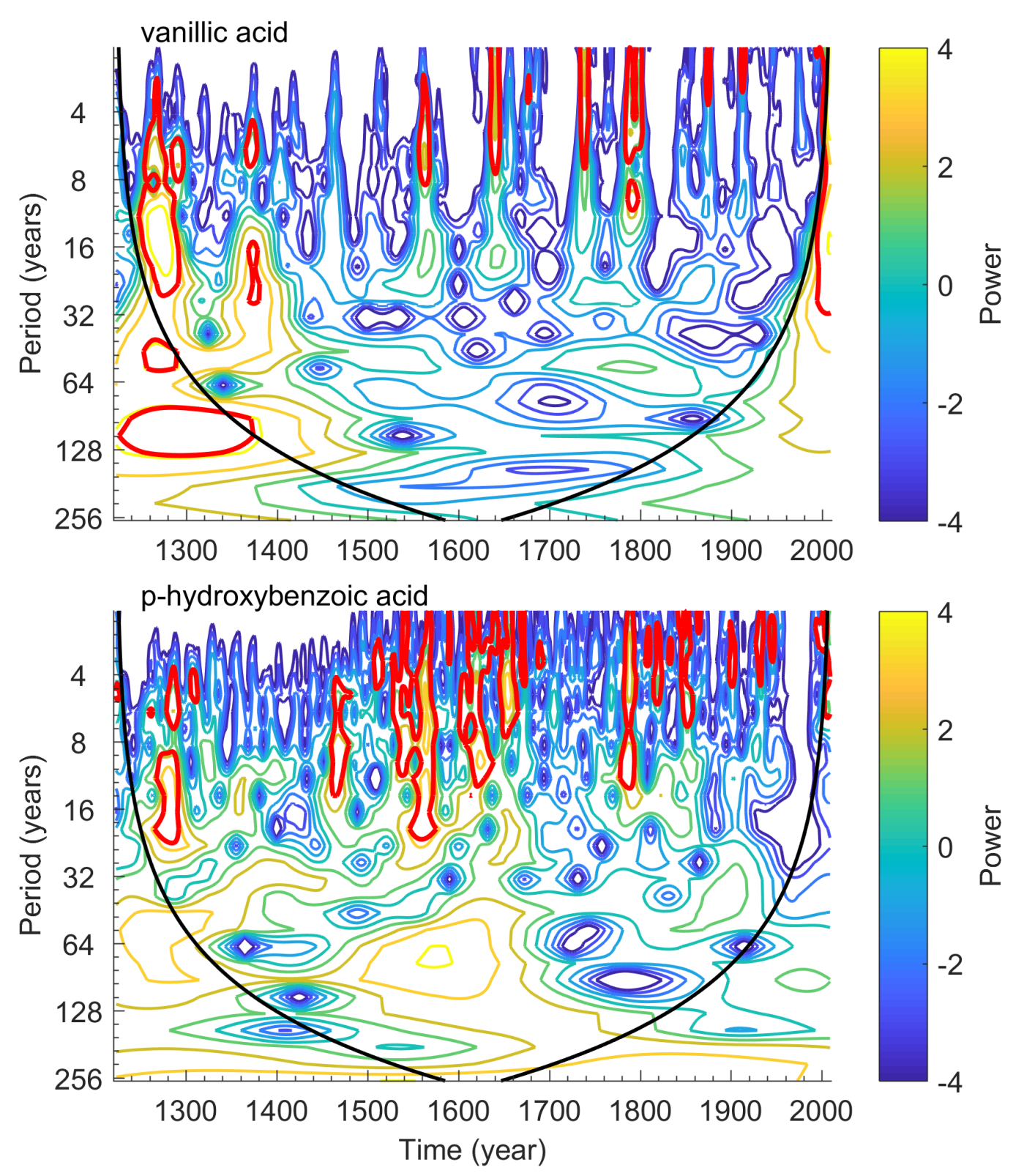

Figure S9. Wavelet analysis of aromatic acids in the Lomonosovfonna, Svalbard ice core: vanillic acid (top) and p-hydroxybenzoic acid (bottom). Black curves are the cones of influence. The red outlines are the 95\% confidence interval. Power for wavelet transforms is defined as the logarithm base 2 of the wavelet transform. The continuous wavelet analysis of the data was carried out using MATLAB by interpolating the raw data sets to 1 sample year-1, linear detrending, and applying a Morlet wavelet using the "wavelet" and "wave_signif" functions (Torrence and Compo, 1998). Both VA and p-HBA exhibit peaks in power at $\sim 100$-year and $\sim 50$-year periods early in the record (1200$1400 \mathrm{CE}$ ). These peaks are within the $90 \%$ confidence interval, but outside of the cone of influence. The VA peak in power at a $\sim 100$-year period decreases until about $1500 \mathrm{CE}$. The p-HBA peak in power at a $\sim 100$-year period is steady until after $1600 \mathrm{CE}$. The largest amplitude feature in p-HBA occurs over an 80-100-year period from 1500-1600 CE. This peak in within the $90 \%$ confidence interval. 

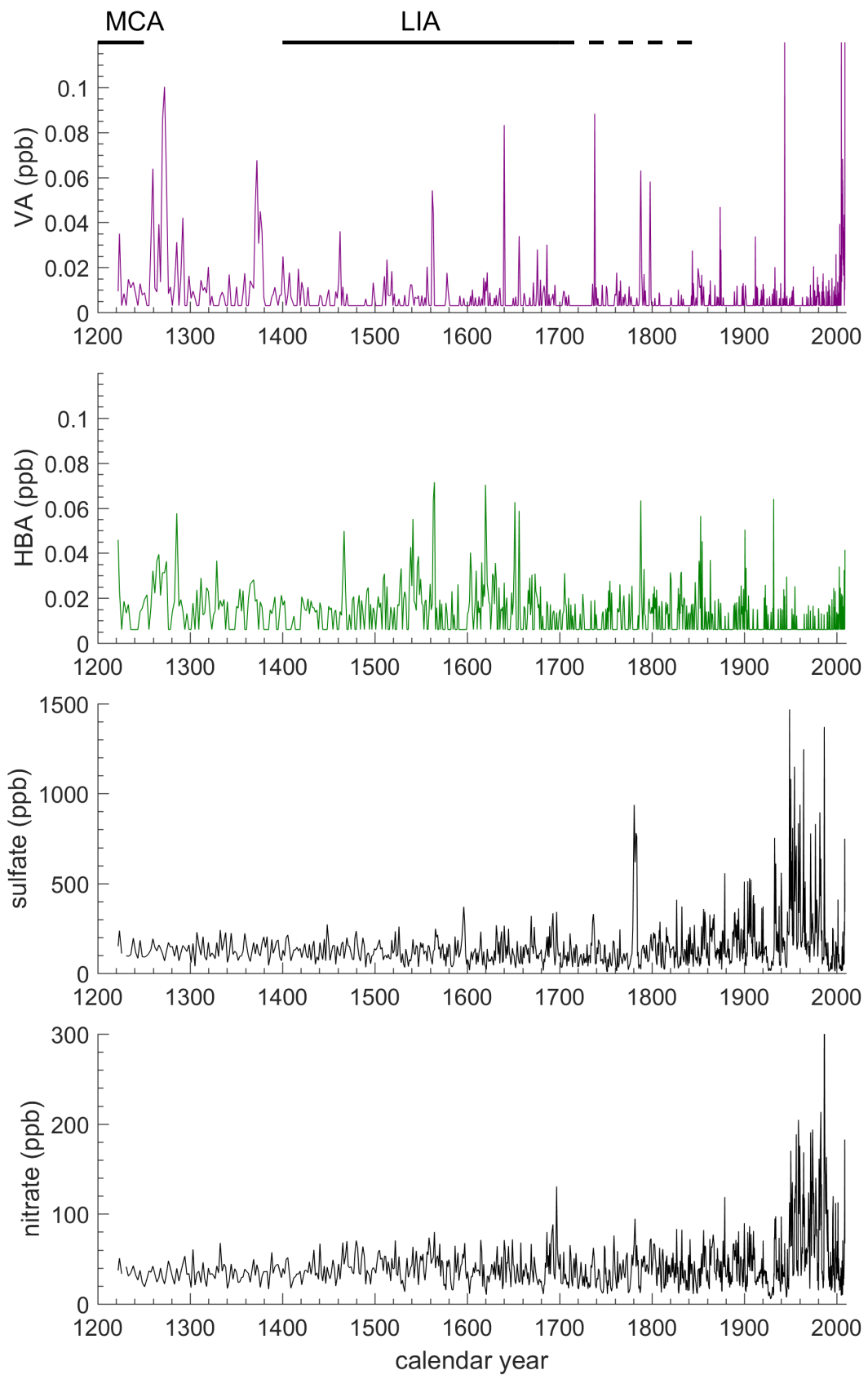

Figure S10. Relationship between Lomonosovfonna vanillic acid, para-hydroxybenzoic acid, nitrate, and sulfate (Wendl et al., 2015). The black horizontal lines are the Medieval Climate Anomaly (MCA) and the Little Ice Age (LIA) (Mann et al., 2009). The dashed horizontal line is the extended LIA in the Svalbard region (Divine et al., 2011). 

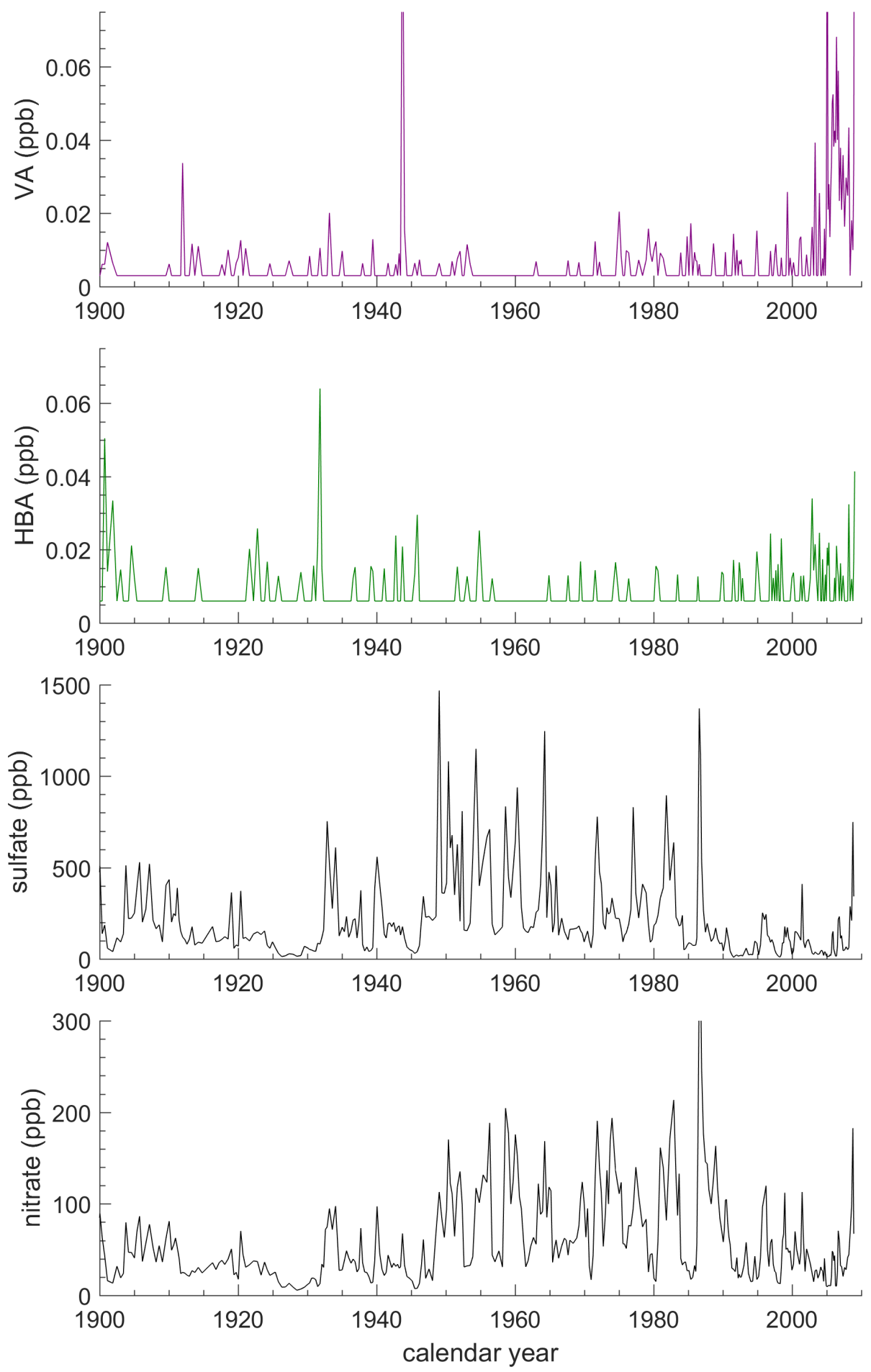

Figure S11. Relationship between Lomonosovfonna vanillic acid, para-hydroxybenzoic acid, nitrate, and sulfate (Wendl et al., 2015) in the 20th century. 

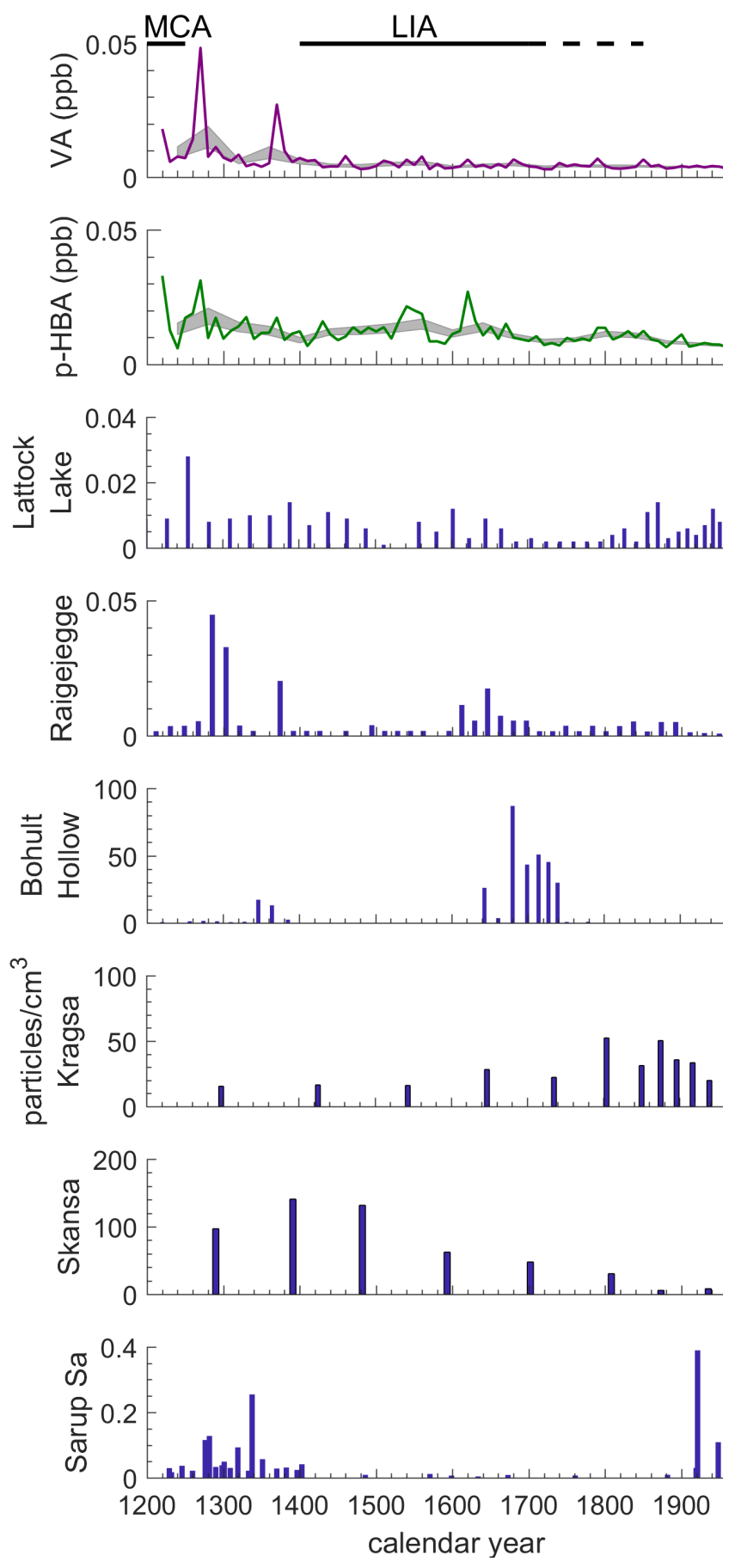

Figure S12. Comparison of the timing of aromatic acid signals in the Lomonosovfonna ice core over the past 800 years compared to Fennoscandia charcoal records. From top: 10-year bin averages of Lomonosovfonna vanillic acid (VA) and p-hydroxybenzoic acid (p-HBA); and charcoal influx records from Lattock Lake, Raigejegge, Bohult Hollow, Skansa, and Sarup Sa (Blarquez et al., 2014). The black horizontal lines are the Medieval Climate Anomaly (MCA) and the Little Ice Age (LIA) (Mann et al., 2009). The dashed horizontal line is the extended LIA in the Svalbard region (Divine et al., 2011). 


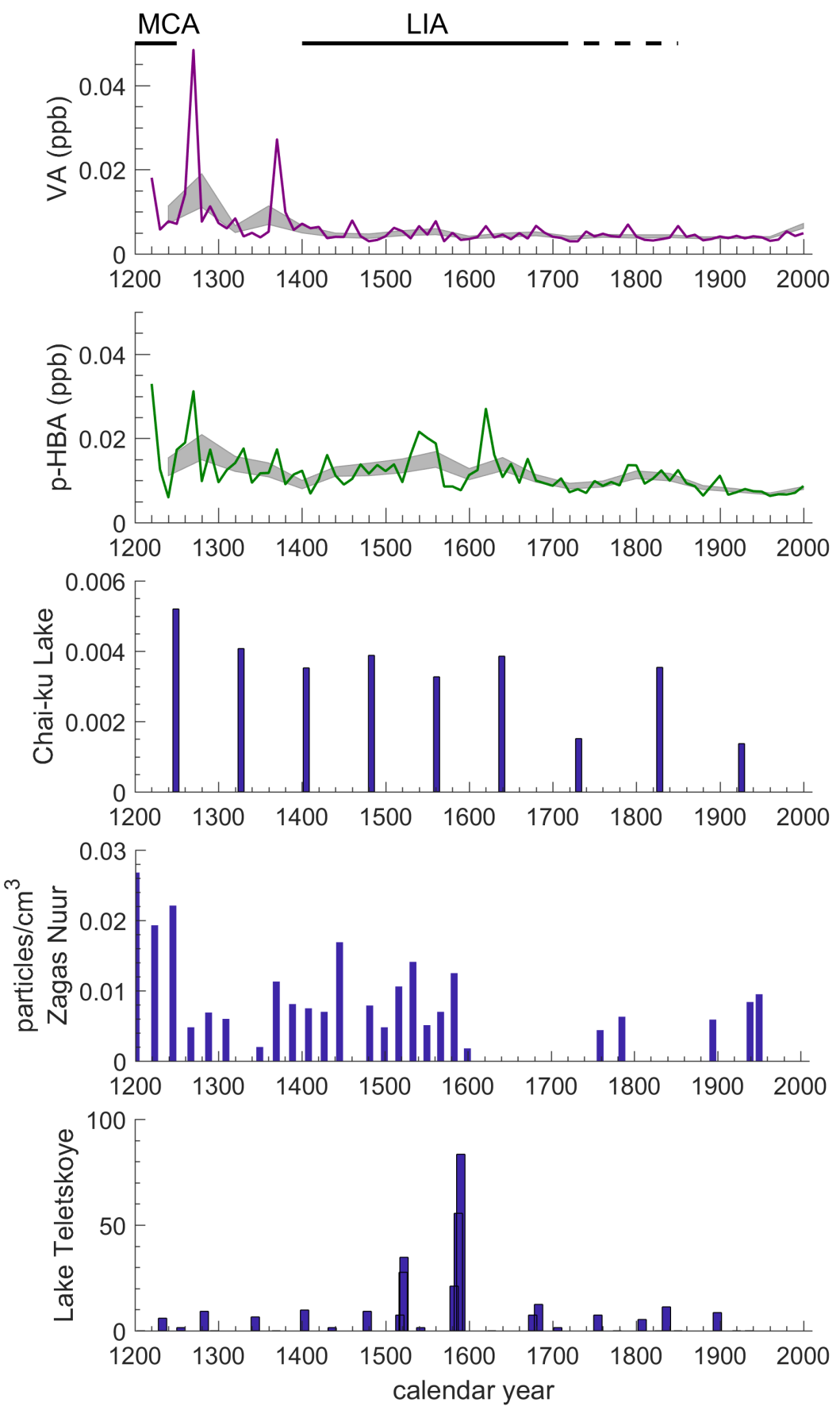

Figure S13. Comparison of the timing of aromatic acid signals in the Lomonosovfonna ice core over the past 800 years compared to Siberian charcoal records. From top: 10-year bin averages of Lomonosovfonna vanillic acid (VA) and p-hydroxybenzoic acid (p-HBA); and charcoal influx records from Chai-ku Lake, Zagas Nuur, and Lake Teletskoye (Blarquez et al., 2014). The black horizontal lines are the Medieval Climate Anomaly (MCA) and the Little Ice Age (LIA) (Mann et al., 2009). The dashed horizontal line is the extended LIA in the Svalbard region (Divine et al., 2011). 

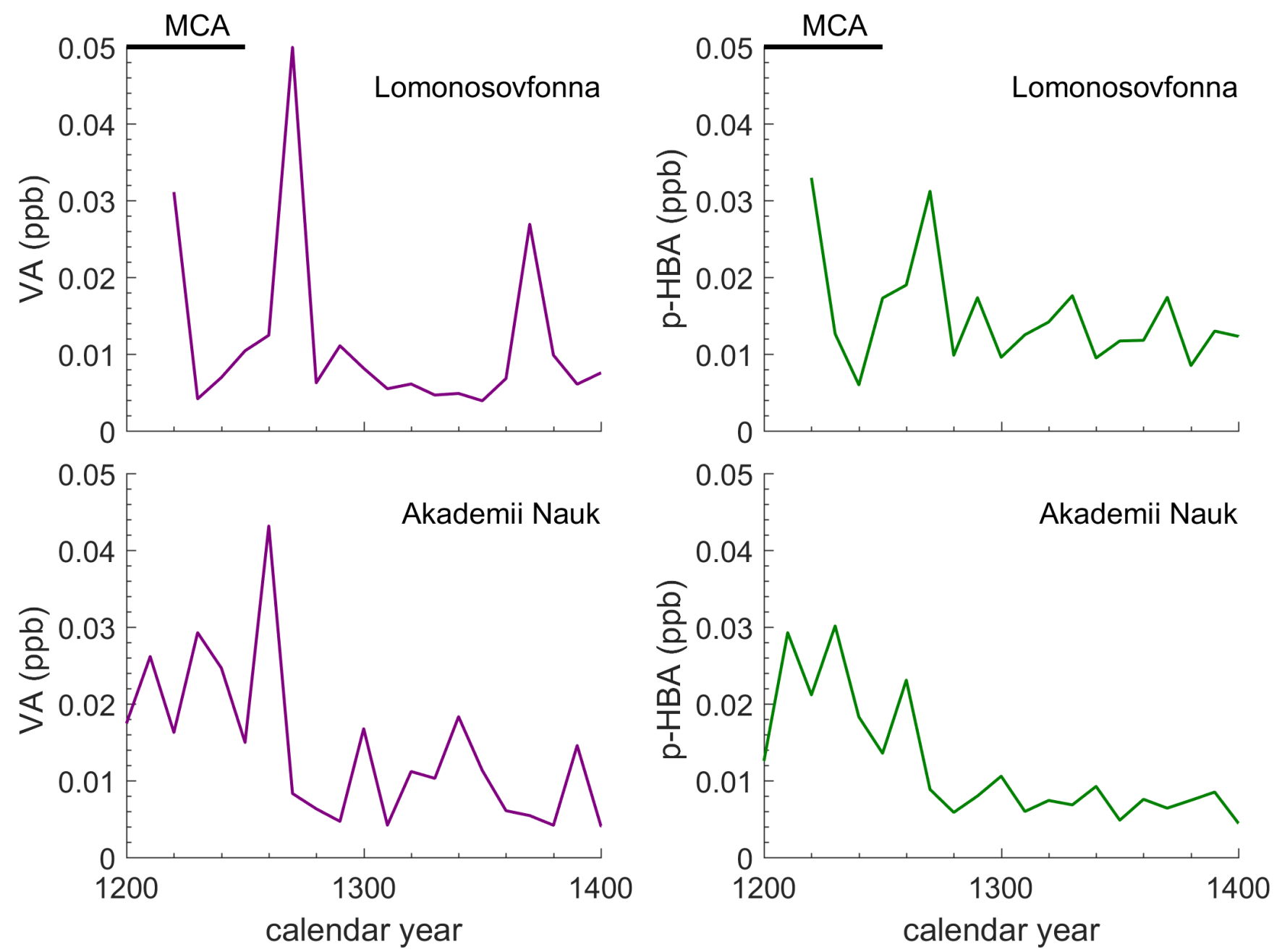

Figure S14. Aromatic acids in the Lomonosovfonna, Svalbard and Akademii Nauk ice cores from 1200-1400 CE. Left: vanillic acid, Right: p-hydroxybenzoic acid. Top: are 10-year bin averages of the Lomonosovfonna ice core measurements. Bottom: 10-year bin averages of the Akademii Nauk ice core measurements (Grieman et al., 2017). The black horizontal lines are the Medieval Climate Anomaly (MCA) (Mann et al., 2009). 
Table S1. Fractions of air mass back trajectories transecting or originating from various geographic regions and ecofloristic zones starting from the Lomonosovfonna (Lomo) and Akademii Nauk (AN) drilling sites from 2006-2015 (\% rounded to nearest integer). Food and Agriculture Organization definitions of the Ecofloristic zones (Fig. S3; http://cdiac.ornl.gov/epubs/ndp/global_carbon/carbon_documentation.html; Ruesch and Gibbs, 2008). The sum of these values can be $>100 \%$ if the trajectories transect multiple ecofloristic zones or $<100 \%$ if trajectories do not reach latitudes below the Arctic. Trajectories commonly do not reach lower latitudes in the summer due to the more northerly position of the Arctic Front relative to the winter (Stohl, 2006).

\begin{tabular}{llllllll}
\hline & & \multicolumn{7}{c}{ Season } \\
\cline { 3 - 8 } Geographic region & Ecofloristic zone & Spring & & Summer & \multicolumn{2}{c}{ Fall } \\
\hline \multirow{2}{*}{ Siberia } & Lomo & AN & Lomo & AN & Lomo & AN \\
& Boreal tundra woodland & 20 & 36 & 5 & 7 & 22 & 40 \\
& Boreal coniferous forest & 14 & 23 & 3 & 3 & 16 & 32 \\
& Boreal mountain system & 9 & 17 & 2 & 2 & 11 & 22 \\
& Temperate steppe & 2 & 4 & 0 & 0 & 2 & 3 \\
\multirow{5}{*}{ Europe } & Temperate continental forest & 3 & 5 & 0 & 0 & 2 & 5 \\
& Boreal tundra woodland & 2 & 1 & 3 & 1 & 3 & 1 \\
& Boreal coniferous forest & 5 & 1 & 8 & 2 & 8 & 1 \\
& Boreal mountain system & 6 & 1 & 10 & 3 & 11 & 2 \\
& Temperate oceanic forest & 2 & 0 & 4 & 0 & 5 & 1 \\
& Temperate continental forest & 2 & 0 & 1 & 0 & 4 & 1 \\
& Boreal tundra woodland & 4 & 1 & 2 & 1 & 2 & 0 \\
& Boreal coniferous forest & 1 & 0 & 1 & 0 & 1 & 0 \\
\hline
\end{tabular}


Table S2. Vanillic acid (VA) emissions, para-hydroxybenzoic acid (p-HBA) emissions, and the ratio of vanillic acid to para-hydroxybenzoic acid emissions in laboratory studies.

\begin{tabular}{|c|c|c|c|c|}
\hline plant type & VA (mg/kg fuel burned) & p-HBA (mg/kg fuel burned) & VA/p-HBA & reference \\
\hline Apache pine & 6.707 & & & Oros and Simoneit (2001a) \\
\hline California redwood & 1.126 & 2.618 & 0.43 & Oros and Simoneit (2001a) \\
\hline Douglas fir & 4.307 & 4.345 & 0.99 & Oros and Simoneit (2001a) \\
\hline Eastern White pine & 8.351 & & & Oros and Simoneit (2001a) \\
\hline Lodgepole pine & 3.609 & 5.807 & 0.62 & Oros and Simoneit (2001a) \\
\hline Montezuma pine & 5.706 & & & Oros and Simoneit (2001a) \\
\hline Mountain hemlock & 1.783 & 4.425 & 0.40 & Oros and Simoneit (2001a) \\
\hline Noble fir & & 3.559 & & Oros and Simoneit (2001a) \\
\hline Pacific Silver fir & 7.833 & 23.206 & 0.34 & Oros and Simoneit (2001a) \\
\hline Ponderosa pine & 0.790 & 0.040 & 19.75 & Oros and Simoneit (2001a) \\
\hline Port Orford cedar & 5.125 & & & Oros and Simoneit (2001a) \\
\hline Sitka spruce & 2.194 & 2.968 & 0.74 & Oros and Simoneit (2001a) \\
\hline Western White pine & 0.477 & & & Oros and Simoneit (2001a) \\
\hline Eucalyptus & 57 & & & Oros and Simoneit (2001b) \\
\hline Oregon maple & 4547 & & & Oros and Simoneit (2001b) \\
\hline Red alder & 1225 & & & Oros and Simoneit (2001b) \\
\hline Silver birch & 1775 & & & Oros and Simoneit (2001b) \\
\hline Dwarf birch & 3393 & & & Oros and Simoneit (2001b) \\
\hline Tundra grass & & 0.001695 & & Oros et al. (2006) \\
\hline Pine $^{1}$ & 14 & 1.6 & 8.75 & Iinuma et al. (2007) \\
\hline Pine with greens ${ }^{1}$ & 0.56 & 8.1 & 0.07 & Iinuma et al. (2007) \\
\hline Spruce with greens ${ }^{1}$ & 2.6 & 38 & 0.07 & Iinuma et al. (2007) \\
\hline German peat $^{1}$ & 3 & 36 & 0.08 & Iinuma et al. (2007) \\
\hline
\end{tabular}

${ }^{1}$ o- or p-hydroxybenzoic acid isomer not specified 


\section{References}

Blarquez, O., Vannière, B., Marlon, J. R., Daniau, A.-L., Power, M. J., Brewer, S., and Bartlein, P. J.: Paleofire: An R package to analyse sedimentary charcoal records from the Global Charcoal Database to reconstruct past biomass burning, Computers and Geosciences, 72 , 255 - 261, doi:10.1016/j.cageo.2014.07.020, 2014.

5 Divine, D., Isaksson, E., Martma, T., Meijer, H. A., Moore, J., Pohjola, V., van de Wal, R. S. W., and Godtliebsen, F.: Thousand years of winter surface air temperature variations in Svalbard and northern Norway reconstructed from ice-core data, Polar Research, 30, 7379, doi:10.3402/polar.v30i0.7379, 2011.

Grieman, M. M., Aydin, M., Fritzsche, D., McConnell, J. R., Opel, T., Sigl, M., and Saltzman, E. S.: Aromatic acids in a Eurasian Arctic ice core: a 2600-year proxy record of biomass burning, Climate of the Past, 13, 395-410, doi:10.5194/cp-13-395-2017, 2017.

Iinuma, Y., Brüggemann, E., Gnauk, T., Müller, K., Andreae, M. O., Helas, G., Parmar, R., and Herrmann, H.: Source characterization of biomass burning particles: The combustion of selected European conifers, African hardwood, savanna grass, and German and Indonesian peat, Journal of Geophysical Research: Atmospheres, 112, D08 209, doi:10.1029/2006JD007120, 2007.

Mann, M. E., Zhang, Z., Rutherford, S., Bradley, R. S., Hughes, M. K., Shindell, D., Ammann, C., Faluvegi, G., and Ni, F.: Global Signatures and Dynamical Origins of the Little Ice Age and Medieval Climate Anomaly, Science, 326, 1256-1260, doi:10.1126/science.1177303, 2009.

Oros, D. R. and Simoneit, B. R. T.: Identification and emission factors of molecular tracers in organic aerosols from biomass burning Part 1. Temperate climate conifers, Applied Geochemistry, 16, 1513-1544, doi:10.1016/s0883-2927(01)00021-x, 2001a.

Oros, D. R. and Simoneit, B. R. T.: Identification and emission factors of molecular tracers in organic aerosols from biomass burning Part 2. Deciduous trees, Applied Geochemistry, 16, 1545-1565, doi:10.1016/S0883-2927(01)00022-1, 2001b.

Oros, D. R., Abas, M. R. b., Omar, N. Y. M. J., Rahman, N. A., and Simoneit, B. R. T.: Identification and emission factors of molecular tracers in organic aerosols from biomass burning: Part 3. Grasses, Applied Geochemistry, 21, 919-940, doi:10.1016/j.apgeochem.2006.01.008, 2006.

Ruesch, A. and Gibbs, H. K.: New IPCC Tier-1 global biomass carbon map for the year 2000, Carbon Dioxide Information Analysis Center, Oak Ridge National Laboratory, 2008.

Stohl, A.: Characteristics of atmospheric transport into the Arctic troposphere, Journal of Geophysical Research: Atmospheres, 111, doi:10.1029/2005JD006888, 2006.

Torrence, C. and Compo, G. P.: A practical guide to wavelet analysis, Bulletin of the American Meteorological society, 79, 61-78, doi:10.1175/1520-0477(1998)079<0061:APGTWA>2.0.CO;2, 1998.

Wendl, I., Eichler, A., Isaksson, E., Martma, T., and Schwikowski, M.: 800-year ice-core record of nitrogen deposition in Svalbard linked to ocean productivity and biogenic emissions, Atmospheric Chemistry and Physics, 15, 7287-7300, doi:10.5194/acp-15-7287-2015, 2015. 